\title{
Faktor-faktor yang mempengaruhi ibu dalam perawatan bayi berat badan lahir rendah: Scoping review
}

\author{
Yayu Yuliarti ${ }^{1^{*}}$, Nurul Kurniati ${ }^{2}$, Herlin Fitriana Kurniawati ${ }^{3}$ \\ 1,2,3 Universitas 'Aisyiyah Yogyakarta
}

\begin{tabular}{l} 
INFORMASI ARTIKEL: \\
\hline Riwayat Artikel: \\
Tanggal diterima: 25 Mei 2021 \\
Tanggal direvisi: 23 Juni 2021 \\
Tanggal dipublikasi: 26 Juli 2021 \\
\hline Kata kunci: \\
Ibu \\
Perawatan \\
Bayi \\
Faktor Internal \\
Faktor eksternal \\
BBLR
\end{tabular}

Keyword :

Mother

Care

Infant

Internal Factors

External Factors

Low Birth Weight

\begin{abstract}
Latar Belakang: Bayi Berat Lahir Rendah (BBLR) adalah bayi yang lahir dengan berat kurang dari 2500 gram. BBLR terus menjadi masalah kesehatan masyarakat yang signifikan secara global karena efek jangka pendek dan jangka panjangnya terhadap kesehatan. BBLR bukan hanya penyebab utama kematian prenatal dan penyebab sakit. Penyebab kematian bayi dan neonatal yang paling sering adalah BBLR dan sepsis. Tujuan: Scoping review bertujuan untuk mengkaji bukti faktor-faktor yang mempengaruhi ibu dalam merawat bayi berat lahir rendah. Metode: Tinjauan pelingkupan ini menggunakan kerangka kerja Arksey dan O'Malley Identifikasi studi yang relevan dari 2009-2019 menggunakan 4 database. Hasil Scoping review ini terdiri dari 11 artikel dari 394 artikel, ditemukan 2 tema yaitu faktor internal dan faktor eksternal. Simpulan: Ada 2 faktor yang mempengaruhi ibu dalam merawat bayi BBLR yaitu faktor internal dan faktor eksternal. Faktor internal meliputi pengetahuan ibu dalam merawat bayi BBLR dan psikologi ibu dengan BBLR. Faktor eksternal ibu meliputi dukungan sosial ibu dalam merawat bayi BBLR dan faktor ekonomi. Faktor internal yang paling mempengaruhi ibu dalam merawat bayi BBLR adalah faktor psikologis ibu, sedangkan faktor eksternal adalah dukungan sosial
\end{abstract}

Background: Low Birth Weight (LBW) is a baby born weighing less than 2500 grams. $L B W$ continues to be a significant public health problem globally due to its short and long term effects on health. LBW is not only the main cause of prenatal mortality and a cause of illness. The common cause of infant and neonatal mortality is LBW and sepsis. Objective: The objective of the scoping review is to review the evidence of factors influencing mothers to care for low birth weight babies. Methods This scoping review used Arksey and O'Malley's framework Identification of relevant studies from 2009-2019 using 4 databases. Results This scoping review consisted of 11 articles from 394 articles, 2 themes were found, which were internal factors and external factors. Conclusion: There are 2 factors that influence mothers in caring for LBW infant which are internal factors and external factors. Internal factors include the knowledge of mothers in caring for low-birth-weight babies and psychology of mothers with low-birthweight babies. Maternal external factors include social support for mothers in caring for LBW infant and economic factors. The internal factor that most influences the mother in caring for LBW infant is the mother's psychology, while the external factor is social support.

efek jangka pendek dan jangka panjangnya terhadap kesehatan (WHO, 2014). Salah satu tindakan yang dapat diberikan pada bayi dengan BBLR adalah dengan menggunakan metode Kangaroo Mother Care (KMC). Cara ini merupakan terapi gratis yang bisa dilakukan ibu karena tidak semua bayi BBLR bisa mendapatkan pelayanan kesehatan dengan menggunakan teknologi canggih. Umumnya disebabkan faktor sosial ekonomi, geografi, transportasi, dan komunikasi yang rendah. KMC pertama kali diterapkan di Bogota, Kolombia dengan tujuan untuk

\footnotetext{
* Korespondensi penulis.

Email: yayuyuliartiaryo89@gmail.com.
} 
mengurangi angka morbiditas dan mortalitas yang tinggi pada BBLR karena keterbatasan sumber daya di ruang NICU (Neonatal Intensive Care Unit). Bayi dengan BBLR yang mendapat pengobatan KMC akan memiliki pengalaman psikologis dan emosional yang lebih baik karena dengan metode ini bayi akan mendapatkan kehangatan dan kedekatan dengan ibu sehingga dapat meningkatkan kualitas hidup bayi (Solehati et al., 2018). Secara umum penyebab BBLR pada bayi adalah multifaktorial. Namun penyebab yang paling berpengaruh adalah kelahiran prematur (Breivold et al., 2019). Bayi BBLR akan mengalami risiko gangguan pada sistem tubuh, gangguan pernafasan, gangguan gizi dan juga rentan terhadap infeksi karena daya tahan tubuh yang masih lemah, kemampuan leukosit yang masih kurang dan pembentukan antibodi yang belum sempurna (Chang Lee et.al., 2009). Faktor-faktor yang mempengaruhi perawatan bayi BBLR antara lain tingkat pendidikan orang tua, sosial budaya setempat, informasi dari petugas kesehatan, sosial ekonomi, dukungan dari suami dan keluarga serta tenaga kesehatan. Faktor ibu sangat erat kaitannya dengan pertumbuhan janin. Dengan mengetahui faktor-faktor yang berhubungan dengan BBLR maka jumlah bayi berat lahir rendah dapat diturunkan (Cho et al., 2016). Oleh karena itu, bayi BBLR sangat membutuhkan perhatian khusus dan perawatan intensif di rumah sakit di NICU (Neonatal Intensive Care Unit) untuk membantu mengembangkan fungsi bayi secara optimal (Solehati et al., 2018). Faktor ibu sangat erat kaitannya dengan pertumbuhan janin. Dengan mengetahui faktor-faktor yang berhubungan dengan BBLR maka jumlah bayi berat lahir rendah dapat diminimalisir (Conde et al., 2016). Berdasarkan latar belakang diatas maka peneliti melakukan tinjauan pustaka untuk menggali faktor-faktor yang mempengaruhi ibu dalam merawat bayi berat lahir rendah. Tujuan penyusunan scoping review ini adalah untuk mengkaji bukti faktor-faktor yang mempengaruhi ibu dalam merawat bayi BBLR yang meliputi, faktor internal ibu yang merawat bayi BBLR, respon awal ibu dalam merawat BBLR. bayi, psikologi ibu dalam merawat bayi BBLR, faktor eksternal ibu dalam merawat bayi BBLR, dukungan sosial ibu dalam merawat bayi BBLR dan faktor sosial budaya ibu dalam merawat bayi BBLR. Tujuan dari scoping review ini adalah untuk menginterpretasikan faktor-faktor yang mempengaruhi ibu dalam merawat bayi BBLR. Respon awal ibu dalam merawat bayi BBLR, psikologi ibu dalam merawat bayi BBLR, faktor eksternal ibu dalam merawat bayi BBLR, dukungan sosial ibu dalam merawat bayi BBLR dan faktor sosial budaya bagi ibu dalam merawat bayi berat lahir rendah. Tujuan dari scoping review ini adalah untuk menginterpretasikan faktor-faktor yang mempengaruhi ibu dalam merawat bayi BBLR. Respon awal ibu dalam merawat bayi BBLR, psikologi ibu dalam merawat bayi BBLR, faktor eksternal ibu dalam merawat bayi BBLR, dukungan sosial ibu dalam merawat bayi BBLR dan faktor sosial budaya bagi ibu dalam merawat bayi berat lahir rendah.

\section{Metode Penelitian}

Scoping review adalah metode yang digunakan untuk mengidentifikasi kesenjangan penelitian dalam sebuah penelitian dan mengidentifikasi keterlibatan dalam pengambilan keputusan (Tricco et.al, 2016). Kerangka yang digunakan dalam ulasan ini didasarkan pada kerangka Arksey dan O'Malley (2013). Adapun langkah-langkah dari framework Arksey and O'Malley yaitu (1) Identifikasi pertanyaan scoping review, (2) Identifikasi artikel yang relevan, (3) Seleksi artikel, (4) Data Charting, (5) Maping, collating and summarizing.

\section{Langkah 1: Identifikasi pertanyaan scoping review}

Pertanyaan dalam scoping review ini yaitu "adalah apa saja faktor-faktor yang mempengaruhi ibu dalam merawat bayi berat badan lahir rendah?"dalam mengembangkan strategi pencarian dan merumuskan pertanyaan scoping review artikel menggunakan format PEOs (Population, Exposure, Outcomes). Penggunaan PEOs ini membantu mengidentifikasi aspek-aspek yang terpisah dan dapat dicari dari situasi di mana populasi memiliki kondisi tertentu dan hasil yang diinginkan terkait dengan intervensi.

Tabel 1. PEOs

\begin{tabular}{lll}
\hline Population & E & \multicolumn{1}{c}{ Os } \\
\hline $\begin{array}{l}\text { Mothers, } \\
\text { Womens }\end{array}$ & Factors & $\begin{array}{l}\text { Experience in caring the low } \\
\text { birth weight infant, the factor of } \\
\text { postpartum }\end{array}$ \\
& $\begin{array}{l}\text { caring the low birth weight } \\
\text { infant, the resistance of caring } \\
\text { the low birth weight infant }\end{array}$ \\
\hline
\end{tabular}




\section{Langkah 2 : Identifikasi Artikel yang Relevan}

Studi ini menggunakan tools melalui 4 database, yaitu PubMed, Science direct, EBSCO dan Wiley. Kata yang menjadi keyword dalam proses pencarian tersebut diantaranya adalah " Postpartum mothers, internal factors, external factors, low birth weight" dan ditambah keyword pendukung dan keyword lain yang merupakan padanan kata dari keyword utama untuk memperluas pencarian kemudian mengatur dan melakukan penyaringan sesuai kriteria inklusi dan eksklusi pada Tabel 2. Data disaring sesuai dengan kriteria inklusi yang digunakan yaitu artikel yang diterbitkan tahun 2009-2019.

Tabel 2. Kriteria Inklusi dan Eksklusi

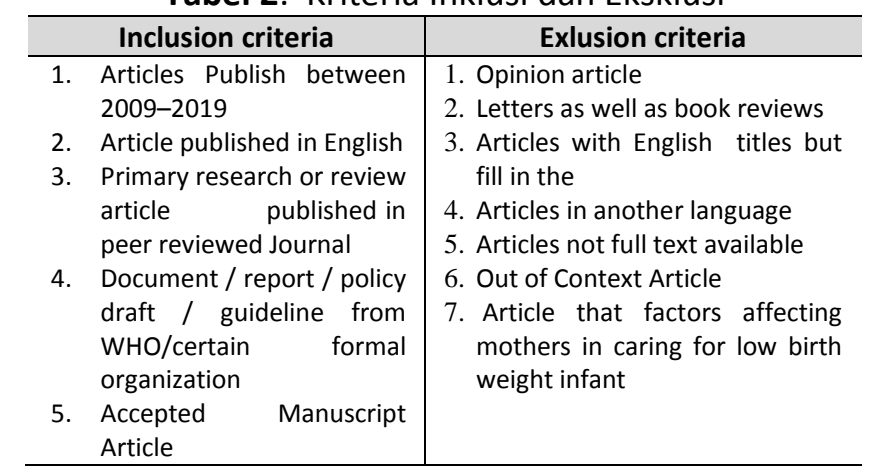

\section{Langkah 3: Seleksi Artikel}

Hasil pencarian dari 4 database dan reference list didapatkan jumlah 394 artikel, kemudian beberapa artikel yang double/duplikat dihapus sehingga didapatkan 273 artikel. Dari 273 artikel dilakukan penyaringan berdasarkan title dan abstract review artikel yang berhubungan dengan pengalaman ibu dalam merawat bayi berat badan rendah didapatkan 258 artikel. Berdasarkan pencarian 258 full text artikel yang teridentifikasi dilakukan untuk penyaringan isi artikel dan berdasarkan kriteria inklusi dan eksklusi. Dari hasil skrining full text, kesesuaian populasi, metode, dan hasil didapatkan 11 artikel yang dianggap memenuhi kriteria inklusi dan eksklusi serta dilakukan data charting dan quality assessment. Hasil pencarian dan skrining artikel akan ditampilkan dalam bentuk gambar 1 PRISMA Flowchart.

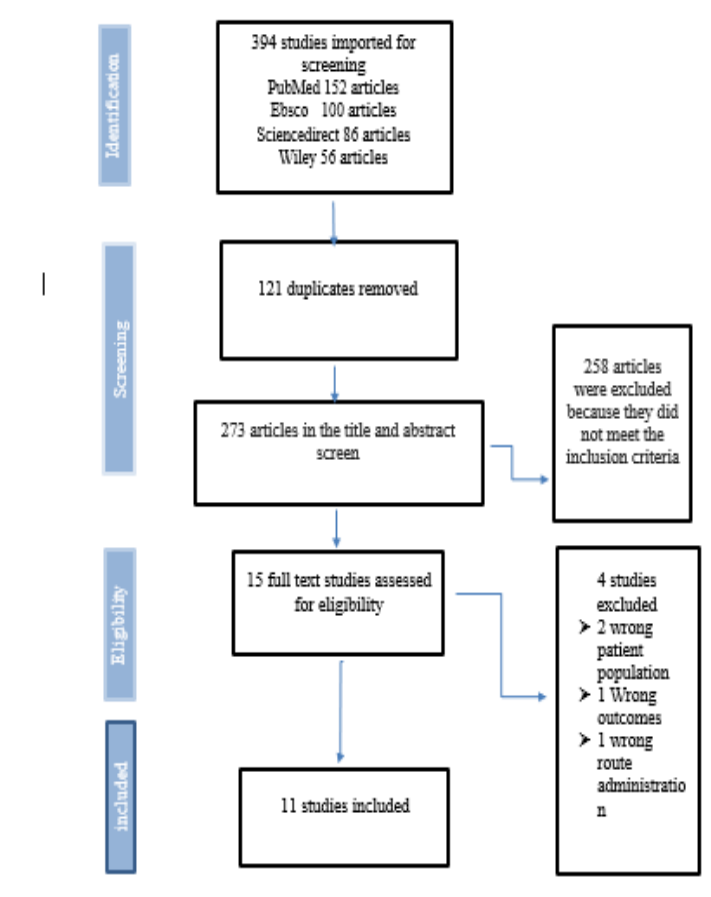

Gambar 1. PRISMA Flowchart

Alat yang dipilih untuk menilai kualitas artikel adalah ceklist Joana Brigs dari Joana Brigs Institute yang mana merupakan suatu alat penilaian yang digunakan untuk menilai kualitas metodologis suatu penelitian dan untuk menentukan sejauh mana dimana penelitian telah membahas kemungkinan bias dalam desain, pelaksanaan dan analisisnya. Critical Appraisal dilakukan kepada 11 artikel, menghasilkan 9 artikel berkualitas baik dan 2 artikel berkualitas cukup. 


\section{Langkah 4: Data Charting}

Berdasarkan 11 artikel yang telah terpilih, selanjutnya dilakukan charting data untuk menggolongkan beberapa poin atau bagian dari artikel seperti tujuan penelitian, desain penelitian, jumlah sampel, dan hasil atau temuan dari penelitian tersebut.

Tabel 3. Charting Data

\begin{tabular}{|c|c|c|c|c|c|}
\hline Kode & $\begin{array}{c}\text { Judul / penulis / } \\
\text { tahun }\end{array}$ & Negara & Tujuan & Metode & Hasil \\
\hline 1 & $\begin{array}{l}\text { Mothers' } \\
\text { experiences after } \\
\text { coming home from } \\
\text { the hospital with a } \\
\text { moderately to late } \\
\text { preterm infant - a } \\
\text { qualitative } \\
\text { studv(Breivold et al }\end{array}$ & Norwegia & $\begin{array}{l}\text { Penelitian ini bertujuan untuk } \\
\text { mengeksplorasi pengalaman ibu } \\
\text { setelah pulang dari rumah sakit } \\
\text { dalam perawatan bayi prematur } \\
\text { berat badan lahir rendah }\end{array}$ & $\begin{array}{l}\text { Kualitatif / } \\
\text { Indept } \\
\text { Interview }\end{array}$ & $\begin{array}{l}\text { Berdasarkan hasil penelitian ini adalah } \\
\text { bantuan dan dukungan praktis dari orang- } \\
\text { orang dekat, dikombinasikan dengan tindak } \\
\text { lanjut profesional perorangan dalam hal ini } \\
\text { penting bagi kemampuan para ibu untuk } \\
\text { mengatasi masa transisi dari rumah sakit ke } \\
\text { rumah. }\end{array}$ \\
\hline
\end{tabular}

2019)

\begin{tabular}{|c|c|c|c|c|c|}
\hline 2 & $\begin{array}{l}\text { The effects of } \\
\text { kangaroo care in } \\
\text { the neonatal } \\
\text { intensive care unit } \\
\text { on the physiological } \\
\text { functions of } \\
\text { preterm infants, } \\
\text { maternal- infant } \\
\text { attachment and } \\
\text { maternal stress } \\
\text { (Cho et al. n.d.) }\end{array}$ & $\begin{array}{l}\text { Korea } \\
\text { Selatan }\end{array}$ & $\begin{array}{l}\text { Penelitian ini dilakukan untuk } \\
\text { mengidentifikasi efek dari } \\
\text { perawatan kangaroo pada fungsi } \\
\text { fisiologis bayi prematur, hubungan } \\
\text { antara ibu dan bayi, serta stress ibu }\end{array}$ & $\begin{array}{l}\text { Quasy } \\
\text { Experiment }\end{array}$ & $\begin{array}{l}\text { Studi ini menunjukan bahwa perawatan } \\
\text { kangaroo dapat digunakan untuk } \\
\text { mempromosikan ikatan emosional anatara } \\
\text { ibu dan bayi serta menstabilkan fungsi } \\
\text { fisiologis (respirasi) bayi prematur. }\end{array}$ \\
\hline 3 & $\begin{array}{l}\text { Taiwanese women's } \\
\text { experiences of } \\
\text { becoming a mother } \\
\text { to a very-low-birth- } \\
\text { weight preterm } \\
\text { infant: A grounded } \\
\text { theory study (Chang } \\
\text { Lee, Long, and } \\
\text { Boore 2009) }\end{array}$ & Taiwan & $\begin{array}{l}\text { Penelitian ini bertujuan untuk } \\
\text { mengeksplorasi pengalaman ibu- } \\
\text { ibu di Taiwan ketika bayi prematur } \\
\text { mereka berada di NICU. }\end{array}$ & Kualitatif & $\begin{array}{l}\text { Studi ini menunjukkan bahwa kelahiran } \\
\text { prematur dalam masa perawatan di NICU } \\
\text { mengakibatkan kendala bagi ibu dalam } \\
\text { membangun interaksi fisik. Namun, dalam } \\
\text { hal ini ibu-ibu di Taiwan diberikan alternatif } \\
\text { untuk kontak dengan bayi secara } \\
\text { emosional, sedangkan interaksi fisik } \\
\text { terbatas. Dalam hal ini mereka semua } \\
\text { secara bertahap melakukan peran sebagai } \\
\text { orangtua. }\end{array}$ \\
\hline 4 & $\begin{array}{l}\text { Swedish mothers' } \\
\text { experience of } \\
\text { continuous } \\
\text { Kangaroo Mother } \\
\text { Care (Blomqvist and } \\
\text { Nyqvist 2011) }\end{array}$ & Swedia & $\begin{array}{l}\text { Untuk mengkarakteristikan } \\
\text { pertama kali bayi menerima } \\
\text { perawatan ibu dengan Kangaroo } \\
\text { Mother Care secara terus menerus } \\
\text { dimulai sejak lahir hingga keluar } \\
\text { dari NICU Swedia dan untuk } \\
\text { mengetahui pengalaman ibu dalam } \\
\text { model perawatan Kangaroo } \\
\text { Mother Care. }\end{array}$ & Kualitatif & $\begin{array}{l}\text { Bayi-bayi yang lahir pada usia kehamilan } \\
31-41 \text { minggu dengan berat badan lahir } \\
\text { berkisar } 1715-3700 \text { gram. Ibu dengan bayi } \\
\text { premature dan cukup bulan ini menunjukan } \\
\text { adanya penerimaaan yang baik terhadap } \\
\text { gagasan memberikan bayi mereka } \\
\text { perawatan dengan Kangaroo Mother Care } \\
\text { selama bayi di NICU. }\end{array}$ \\
\hline 5 & $\begin{array}{l}\text { Very preterm birth: } \\
\text { maternal } \\
\text { experiences of the } \\
\text { neonatal intensive } \\
\text { care environment } \\
\text { (Woodward et al. } \\
\text { 2014) }\end{array}$ & $\begin{array}{l}\text { Amerika } \\
\text { Serikat }\end{array}$ & $\begin{array}{l}\text { Untuk mengidentifikasi faktor- } \\
\text { faktor bayi, ibu dan keluarga yang } \\
\text { menempatkan ibu pada } \\
\text { peningkatan risiko stress ketika } \\
\text { bayi dirawat di NICU yang tinggi } \\
\text { dan membantu pemberian } \\
\text { perawatan secara individual }\end{array}$ & $\begin{array}{l}\text { Studi } \\
\text { Kohort }\end{array}$ & $\begin{array}{l}\text { Ibu yang melaporkan mengalami stress } \\
\text { sedang hingga rendah, dengan perubahan } \\
\text { peran orang tua dianggap paling membuat } \\
\text { stress dan orang tua ketika komunikasi } \\
\text { dengan staf perawat tidak membuat } \\
\text { mereka stress. Prediksi stress secara } \\
\text { keseluruhan termasuk pencapaian } \\
\text { pendidikan ibu yang buruk, peristiwa } \\
\text { kehidupan yang penuh tekanan, depresi } \\
\text { pascakelahiran dan perilaku tidak teratur } \\
\text { ketika gelisah. Stress dalam hal perawatan } \\
\text { bayi di NICU dikaitkan dengan kecemasan } \\
\text { anak dan perkembangan bahasa yang lebih } \\
\text { buruk. }\end{array}$ \\
\hline 6 & $\begin{array}{l}\text { Mothering an } \\
\text { Extremely Low } \\
\text { Birth-Weight Infant } \\
\text { (Schenk and Kelley } \\
\text { 2010) }\end{array}$ & $\begin{array}{l}\text { Amerika } \\
\text { Serikat }\end{array}$ & $\begin{array}{l}\text { Untuk menggambarkan } \\
\text { pengalaman hidup seperti apa } \\
\text { rasanya menjadi seorang ibu dari } \\
\text { bayi berat lahir sangat rendah } \\
\text { selama mereka tinggal bersama } \\
\text { bayi mereka di NICU }\end{array}$ & Kualitatif & $\begin{array}{l}\text { Hasil dari penelitian ini yaitu dari } 9 \\
\text { partisipan mengungkapkan tema utama } \\
\text { adalah "menjadi ibu dan menjalin } \\
\text { hubungan". Selain itu tema kecil yang lazim } \\
\text { yang mengekspresikan kekayaan masing- } \\
\text { masing tema utama disajikan. Tema yang }\end{array}$ \\
\hline
\end{tabular}


terkait dengan "menjadi ibu" adalah khawatir dan takut, kelelahan dan kewajiban di rumah seperti anak-anak dan pekerjaan, menyentuh dan menggendong bayi, mengagumi bayi, tugas menjadi ibu, intuisi dan mengenal bayi, masalah keuangan dan transportasi, dan terima kasih. Tema minor yang terkait dengan "menjalin hubungan" adalah menerima bantuan dari keluarga dan komunitas, doa, dan hubungan dengan dokter dan perawat.

\begin{tabular}{|c|c|c|c|c|c|}
\hline 7 & $\begin{array}{l}\text { A Life Uncertain My } \\
\text { Baby's Vulnerability } \\
: \quad \text { Mothers' Lived } \\
\text { Experience Of } \\
\text { Connection With } \\
\text { Their Preterm } \\
\text { Infants In A } \\
\text { Botswana Neonatal } \\
\text { Intensive Care Unit } \\
\text { (Ncube, Barlow, and } \\
\text { Mayers 2016) }\end{array}$ & $\begin{array}{l}\text { Botswana, } \\
\text { Afrika } \\
\text { Selatan }\end{array}$ & $\begin{array}{l}\text { Untuk mengeksplorasi dan } \\
\text { menggambarkan pengalaman } \\
\text { hidup para ibu mengenai } \\
\text { perawatan bayi prematur yang } \\
\text { dirawat di rumah sakit di unit } \\
\text { neonatal di rumah sakit umum di } \\
\text { Gaborone, Botswana }\end{array}$ & $\begin{array}{l}\text { Kualitatif/ } \\
\text { Indept } \\
\text { Interview }\end{array}$ & $\begin{array}{l}\text { Para ibu dikejutkan oleh kelahiran bayi } \\
\text { prematur yang mendadak dan mengalami } \\
\text { lingkungan neonatal yang mengintimidasi. } \\
\text { Hal ini meningkatkan ketakutan dan } \\
\text { kecemasan mereka dan menunda } \\
\text { perkembangan hubungan ibu dengan bayi. } \\
\text { Dukungan dari staf, ibu-ibu lain di unit } \\
\text { neonatal dan anggota keluarga } \\
\text { memungkinkan para ibu untuk mengatasi } \\
\text { rasa takut mereka dan untuk } \\
\text { mengembangkan hubungan emosional } \\
\text { dengan bayi. }\end{array}$ \\
\hline 8 & 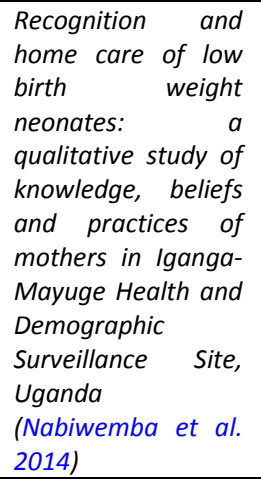 & $\begin{array}{l}\text { Timur } \\
\text { Uganda }\end{array}$ & $\begin{array}{l}\text { Untuk mengeksplorasi } \\
\text { pengetahuan, kepercayaan dan } \\
\text { praktek ibu dalam mengenali dan } \\
\text { menyediakan perawatan di rumah } \\
\text { bagi bayi berat lahir rendah }\end{array}$ & $\begin{array}{l}\text { Kualitatif/ } \\
\text { Indept } \\
\text { Interview }\end{array}$ & $\begin{array}{l}\text { Pengakuan ibu memiliki bayi berat lahir } \\
\text { rendah ketika bayi lahir tidak ditimbang } \\
\text { adalah sulit. Ibu menyadari penyebab berat } \\
\text { lahir rendah meskipun beberapa ibu } \\
\text { percaya pada pengaruh kekuatan gaib. Ibu } \\
\text { yang melahirkan di rumah sakit memiliki } \\
\text { pengetahuan yang lebih baik tentang } \\
\text { praktik perawatan di rumah yang tepat } \\
\text { untuk bayi berat lahir rendah dibandingkan } \\
\text { dengan ibu yang melahirkan di rumah atau } \\
\text { di fasilitas kesehatan tingkat rendah. }\end{array}$ \\
\hline 9 & $\begin{array}{l}\text { The effect of } \\
\text { kangaroo mother } \\
\text { care on mental } \\
\text { health of mothers } \\
\text { with low birth } \\
\text { weight infants } \\
\text { (Badiee, Faramarzi, } \\
\text { and MiriZadeh } \\
\text { 2014) }\end{array}$ & Iran & $\begin{array}{l}\text { Penelitian ini dilakukan untuk } \\
\text { mengevaluasi efek KMC bayi berat } \\
\text { lahir rendah pada kesehatan } \\
\text { mental ibu. }\end{array}$ & RCT & $\begin{array}{l}\text { Skor dari } 50 \text { pasangan bayi-ibu dianalisis } \\
\text { secara total ( } 25 \text { pada kelompok KMC dan } \\
25 \text { pada kelompok perawatan standar). } \\
\text { Hasil analisis kovarians menunjukkan efek } \\
\text { positif KMC pada tingkat skor kesehatan } \\
\text { mental ibu. Ada perbedaan yang signifikan } \\
\text { secara statistik antara skor rata-rata } \\
\text { kelompok eksperimen dan subyek kontrol } \\
\text { dalam periode posttest }(\mathrm{P}<0,001) \text {. }\end{array}$ \\
\hline 10 & $\begin{array}{l}\text { Randomized } \\
\text { controlled trial on } \\
\text { effect r of } \\
\text { intermittent early } \\
\text { versus late } \\
\text { kangaroo mother } \\
\text { care on human milk } \\
\text { feeding in low birth } \\
\text { weight neonates } \\
\text { (Jayaraman et al., } \\
\text { 2017) }\end{array}$ & India & $\begin{array}{l}\text { Tujuan penelitian ini untuk } \\
\text { mengetahui pengaruh kangaroo } \\
\text { mother care yang diberikan segera } \\
\text { setelah bayi lahir terhadap } \\
\text { pemberian asi eksklusif , } \\
\text { pertumbuhan bayi,mortalitas dan } \\
\text { morbiditas pada neonatus BBLR. }\end{array}$ & RCT & $\begin{array}{l}\text { Pemberian perawatan KMC pada BBLR yang } \\
\text { dilakukan lebih awal segera setelah bayi } \\
\text { lahir secara signifikan meningkatkan } \\
\text { pemberian ASI pada bayi BBLR } \\
\text { dibandingkan dengan perawatan KMC yang } \\
\text { diberikan setelah bayi dalam keadaan stabil }\end{array}$ \\
\hline 11 & $\begin{array}{l}\text { Randomized control } \\
\text { trial of kangaroo } \\
\text { mother care in low } \\
\text { birth weight babies } \\
\text { at a tertiary level } \\
\text { hospital (Acharya et } \\
\text { al., 2014) }\end{array}$ & Nepal & $\begin{array}{l}\text { Penelitian ini dilakukan untuk } \\
\text { membandingkan pengaruh } \\
\text { perawatan Kangaroo Mother Care } \\
\text { dan Metode Konvensional pada } \\
\text { bayi prematur }\end{array}$ & RCT & $\begin{array}{l}\text { Hasil dari penelitian ini bayi yang } \\
\text { diberikan metode KMC berat badan nya } \\
\text { bertambah dibanding dengan bayi yang } \\
\text { tidak menerima KMC dan memiliki insiden } \\
\text { hipoermia berkurang dari pada yang tidak } \\
\text { menerima KMC. }\end{array}$ \\
\hline
\end{tabular}




\section{Langkah 5: Mapping Data, Collacting and Summarizing}

Dari 11 artikel yang sesuai dan berkualitas baik, berdasarkan kriteria inklusi yang dibuat, semua artikel yang dipilih berasal dari negara High Income Countries (Amerika Serikat, Swedia, Taiwan, Korea Selatan dan Norwegia) Upper Middle Income Countries (UK, Australia, Denmark, dan Hongkong) dan negara Low Middle Income Countries (LMICs) (Vientiane dan Bhutan). Artikel tersebut kemudian dikelompokkan sesuai dengan negara, didapatkan hasil sebagai berikut :

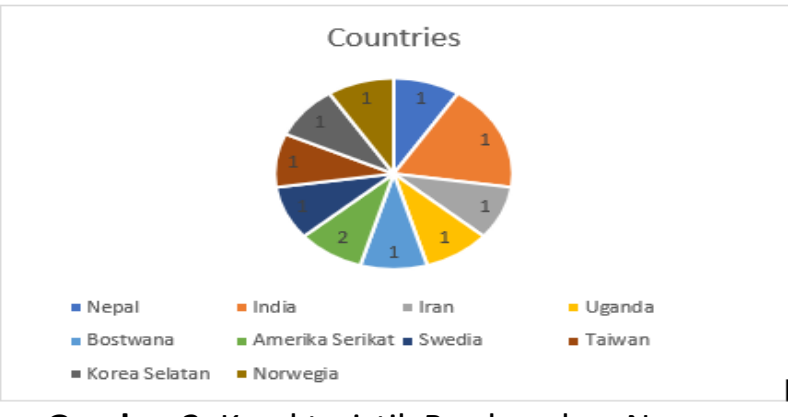

Gambar 2. Karakteristik Berdasarkan Negara

Dari 11 artikel yang dipilih, artikel tersebut kemudian dikelompokkan berdasarkan metode penelitian yang digunakan, didapatkan hasil sebagai berikut:

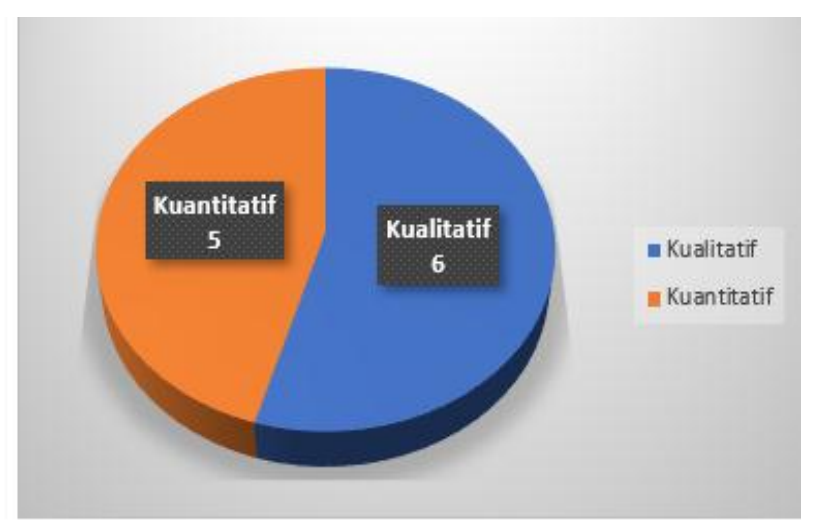

Gambar 3. Metode

Pada langkah maping ini penulis menggolongkan temuan kajian yang menarik diulas di artikel-artikel tersebut, antara lain :

1. Faktor internal

a. Pengetahuan ibu dengan bayi BBLR

b. Psikologi Ibu

2. Faktor Eksternal

a. Dukungan sosial (dukungan suami, dukungan keluarga dan tenaga Kesehatan)

b. Keadaan Ekonomi

\section{Hasil Dan Pembahasan}

Review ini untuk mengeksplorasi faktorfaktor yang mempengaruhi ibu dalam merawat bayi berat badan lahir rendah meliputi faktor internal dan faktor eksternal.

\section{Faktor internal \\ a. Pengetahuan ibu dengan bayi BBLR}

Keluarga khususnya ibu memiliki peran penting dalam merawat dan mengasuh bayinya dengan baik. Hal ini sejalan dengan penelitian yang dilakukan oleh bahwa perawatan ibu pada bayi BBLR sangat berdampak pada kualitas dan pertahanan hidup BBLR dan bila ibu tidak melakukan perawatan dengan baik maka akan berdampak pada angka kejadian infeksi malnutrisi dan kematian pada bayi BBLR. Minimnya informasi yang diterima orang tua tentang tumbuh kembang bayi preterm dan perawatannya dapat mengakibatkan perasaan khawatir, takut dan cemas yang berlarut sehingga berdampak pada ibu kurang dalam berpartisipasi perawatan bayi preterm tersebut (Shonkoff et al., 2012).

Penatalaksanaan bayi BBLR perlu di dukung dengan pengetahuan yang baik, dari pengetahuan ini akan menunjang terhadap pemberian penatalaksanaan yang berkualitas dan aman terhadap bayi BBLR. Dalam hal ini, penatalaksanaan perawatan pada bayi yang dilakukan oleh seorang ibu meliputi mempertahankan suhu dan kehangatan bayi BBLR di rumah, memberikan ASI kepada bayi BBLR di rumah dan mencegah terjadinya infeksi bayi BBLR (Nabiwemba et al., 2014)

Kurangnya informasi yang didapatkan oleh ibu dari tenaga kesehatan khususnya ketika bayi mereka berada di ruang NICU dapat menghambat ibu dalam ikut serta merawat bayinya. Hal tersebut menyebabkan ibu bergantung pada perawat untuk memberikan informasi tentang kebutuhan bayi selama berada di NICU (Chang Lee, Long, and Boore 2009). Sebagian besar ibu kurang mendapatkan informasi tentang perawatan bayi BBLR di NICU (Woodward et al. 2014). Kurangnya pengetahuan ibu dan minimnya informasi yang diberikan oleh tenaga kesehatan dalam perawatan bayi BBLR dengan metode Kangaroo Mother Care, dalam hal ini informasi terkait waktu melakukan dan kapan bisa melakukan KMC belum didapatkan oleh ibu (Blomqvist and Nyqvist, 2011). 


\section{b. Psikologi lbu}

Psikologi ibu digambarkan dengan perasaan frustrasi, serta khawatir bahwa ibu tidak mampu merawat bayi dengan berat badan lahir rendah dan tidak bisa melakukan pekerjaan rumah dengan baik. Hal ini sejalan dengan penelitian yang dilakukan oleh (Schenk and Kelley, 2010) dalam penelitiannya bahwa ibu merasa takut dan khawatir dalam memberikan perawatan pada bayinya di rumah. Ibu merawa tidak memiliki keberanian dan rasa percaya diri dalam merawat bayinya. Hal ini juga sejalan dengan penelitian (Ncube et al., 2016). Adanya ketakutan dan khawatir ibu terhadap perawatan bayinya setelah kepulangan dari rumah sakit, dapat menjadikan ibu bertambah stres dan berdampak pada permasalahan yang cukup panjang seperti : ketidakberdayaan, ketidakmampuan merawat, dan kesulitan memegang bayinya. Hal ini selaras dengan penelitian (Shonkoff et al., 2012) bahwa kapasitas pengasuh dan komunitas didefinisikan sebagai waktu dan komitmen untuk anak, sumber daya yang cukup (misalnya, ekonomi, emosional, psikologis, sosial, dan kelembagaan), dan keterampilan pengasuh dan pengetahuan.

Sebuah tinjauan baru-baru ini terhadap 14 studi menemukan bahwa, secara umum, orang tua dari neonatus yang berisiko tinggi mengalami rasa kehilangan kendali terhadap tanggung jawab pengasuhan, khusunya dalam kasus bayi berat badan lahir rendah. Terlepas dari bukti bahwa faktor orangtua seperti kesehatan mental ibu, pengasuhan dan kohesi keluarga memberikan kontribusi independen yang penting bagi kesehatan bayi (Woodward et al., 2014). Selain itu, hal yang dialami ibu ketika bayi sudah boleh dibawa pulang kerumah yaitu ibu merasa cemas dan kelelahan ketika merawat bayinya dan tidak mendapat dukungan dari keluarga (Acharya et al., 2014). Pengalaman yang menyedihkan bagi orang tua ketika kelahiran bayi dengan berat badan lahir rendah, hal ini seringkali membuat ibu stress sehingga berdampak terhadap kelangsungan hidup dan perkembangan bayi, keraguan akan kemampuan mereka untuk merawat anak, pemisahan dari bayi dengan kesempatan terbatas untuk mengasuh (Badiee, Faramarzi, and Miri Zadeh, 2014). Permasalahn stress yang dihadapi ibu memerlukan perhatian khusus meliputi ; dukungan orang tua (yaitu, psikologis konseling dan dukungan sosial), pendidikan orang tua (yaitu, informasi, demonstrasi dan diskusi, dan aktif keterlibatan dengan umpan balik dari seorang profesional) (Cho et al., 2016).

\section{Faktor Eksternal}

\section{a. Dukungan sosial (dukungan suami, dukungan keluarga dan tenaga Kesehatan)}

Dukungan yang dibutuhkan ibu dalam fase ini berasal dari berbagai sumber lbu menceritakan bahwa suami merupakan dukungan yang paling penting (Chang Lee et al., 2009). Adapun penelitian lain mengatakan bahwa dukungan dari suami sangat penting, namun akses suami dan ibu dalam mendapatkan kesempatan untuk terlibat memberikan asuhan seperti yang dijelasakan bahwa bayi dengan BBLR dianjurkan untuk dilakukan skin to skin oleh keluarga khususnya ibu (Blomqvist and Nyqvist 2011). Hal ini sejalan dengan penelitian yang dilakuakn oleh Woodward et al., (2014) bahwa dukungan keluarga sangat penting untuk mencegah agar ibu tidak cemas dan stress dalam menghadapi kasus dengan bayi berat badan lahir rendah. Bahkan ketika ibu dan bayi sudah diperbolehkan untuk pulang kerumah dan membantu dalam merawat bayi. Selain itu perawat dan dokter memberikan banyak dukungan terhadap ibu baik itu secara khusus seperti staf medis memberikan informasi tentang kondisi dan perawatan bayi sementara perawat memberikan penjelasan kepada ibu dan menawarkan dukungan emosional (Chang Lee et al., 2009).

Keluarga adalah sebagai pemberi dukungan utama yang dapat mempengaruhi pola perawatan bayi berat badan lahir rendah oleh ibu (Woodward et al., 2014). Hal ini sejalan dengan penelitian yang dilakukan oleh Ncube et al., (2014) yang menyatakan bahwa, setiap orangtua yang memiliki bayi berat badan lahir rendah sangat membutuhkan support sistem yang adekuat baik dari dalam keluarga maupun lingkungan diluar keluarga, edukasi berupa pengetahuan cara perawatan bayi preterm yang tepat dan benar, sangat dibutuhkan agar mereka berpartisipasi dengan yakin dan penuh rasa percaya diri dalam perawatan bayinya. Orangtua khususnya ibu dapat melewati masa sulitnya dalam menghadapi kelahiran bayi berat badan lahir rendah, untuk itulah dukungan dari semua pihak terutama petugas kesehatan harus bisa berkomunikasi dengan baik kepada ibu, suami, keluarga (Chang Lee et al., 2009) 
Hasil penelitian yang berjudul "Mothering an Extremely Low Birth-Weight Infant" yang dilakukan oleh Schenk and Kelley (2010), menyatakan bahwa ibu yang melahirkan bayi preterm maupun BBLR, tidak siap dalam mengasuh dan merawat bayi yang preterm serta mengalami kesulitan menjadi seorang ibu pada masa awal kelahiran bayinya. Hal tersebut dikarenakan Ibu mengalami perasaan cemas dan khawatir dengan adanya perawatan yang terpisah dari bayinya. Hal ini sejalan dengan penelitian yang dilakukan oleh (Woodward et al., 2014) dukungan untuk ibu melakukan perawatan bayi berat badan lahir rendah bisa diperoleh dari pihak suami, keluarga dan petugas kesehatan, dukungan yang didapat berupa dukungan emosional, dukungan fisik dan dukungan berupa informasi agar ibu bisa menjalakan perannya dalam merawat bayi berat badan lahir rendah dengan baik

\section{b. Keadaan Ekonomi}

Keadaaan ekonomi juga memepengaruhi dalam mendapatkan perawatan bayi berat badan lahir rendah. Hal ini dijelaskan dalam mendapatkan penanganan layanan fasilitas kesehatan khususnya di ruang NICU memerlukan biaya yang cukup besar (Woodward et al., 2014). Hal ini disejalan dengan penelitian lain bahwa keadaan ekonomi akan mempengaruhi dalam mendapatkan fasilitas perawatan pada bayi berat badan lahir rendah (Nabiwemba et al., 2014).

Penelitian yang dilakukan oleh (Chang Lee et al., 2009) menjelaskan bahwa bayi berat badan rendah (BBLR) tidak harus selalu membutuhkan perawatan di rumah sakit dengan jangka waktu yang lama sehingga memerlukan biaya yang tinggi untuk perawatannya, hal ini tergantung dengan kondisi bayi tersebut. Apabila fungsi organ-organ tubuhnya baik tidak terdapat gangguan seperti gangguan pernafasan dan bayi dapat menghisap dengan baik, maka bayi bisa dibawa pulang untuk dirawat di rumah oleh keluarga.

Faktor sosial ekonomi yang rendah sangat berpengaruh terhadap berat bayi lahir rendah. Hal ini disebabkan ketidakmampuannya memenuhi kebutuhan perawatan ketika bayi masih di rumah sakit (Woodward et al., 2014). Hal ini sejalan dengan penelitian yang dilakukan oleh (Blomqvist and Nyqvist, 2011) dalam memanfaatkan pelayanan kesehatan pada dasarnya pengambilan keputusan dilakukan oleh kepala keluarga, dengan adanya pemanfaatan pelayanan kesehatan menggambarkan kebutuhan pelayanan yang akan diambil. Namun pengambilan keputusan untuk Tindakan perawatan bayi berat badan lahir rendah bisa dipengaruhi oleh keadaaan sosial ekonomi seseorang.

\section{Simpulan}

Terdapat 2 faktor yang mempengaruhi ibu dalam merawat bayi berat badan lahir rendah yaitu faktor internal dan faktor eksternal. Faktor internal meliputi pengetahuan ibu dalam merawat bayi berat badan lahir rendah, psikologis ibu dengan bayi berat badan lahir rendah. Faktor eksternal ibu meliputi dukungan sosial pada ibu dalam merawat bayi berat badan lahir rendah dan faktor ekonomi. Faktor internal yang paling berpengaruh pada ibu dalam merawat bayi berat badan lahir rendah adalah psikologis ibu, sedangkan faktor eksternalnya adalah dukungan sosial.

\section{Daftar Pustaka}

Arksey, H., \& O'Malley, L. (2013). Appendix 1: Methodological Framework ( Arksey \& 0 ' Malley, 2005 ). 2013.

Badiee, Zohreh, Salar Faramarzi, and Tahereh MiriZadeh. 2014. "The Effect of Kangaroo Mother Care on Mental Health of Mothers with Low Birth Weight Infants." Advanced Biomedical Research 3:214.

Breivold, Kristin, Esther Hjaelmhult, Annica Sjöström-Strand, and Inger Kristensson Hallström. 2019. “Mothers' Experiences after Coming Home from the Hospital with a Moderately to Late Preterm Infant - a Qualitative Study." Scandinavian Journal of Caring Sciences 33(3):632-40.

Chang Lee, Shu-Nu, Ann Long, and Jennifer Boore. 2009. "Taiwanese Women's Experiences of Becoming a Mother to a Very-Low-BirthWeight Preterm Infant: A Grounded Theory Study." International Journal of Nursing Studies 46(3):326-36.

Chisenga, Jayne Z., Marcia Chalanda, and Mathews Ngwale. 2015. "Kangaroo Mother Care: A Review of Mothers' Experiences at Bwaila Hospital and Zomba Central Hospital (Malawi)." Midwifery 31(2):305-15. 
Cho, Eun-Sook, Shin-Jeong Kim, Myung Soon Kwon, Haeryun Cho, Eun Hye Kim, Eun Mi Jun, and Sunhee Lee. n.d. 2016. "The Effects of Kangaroo Care in the Neonatal Intensive Care Unit on the Physiological Functions of Preterm Infants, Maternal-Infant Attachment, and Maternal Stress." Journal of Pediatric Nursing 31(4):430-38.

Conde-Agudelo, Agustin, José M. Belizán, and Jose Diaz-Rossello. 2011. "Kangaroo Mother Care to Reduce Morbidity and Mortality in Low Birthweight Infants." in Cochrane Database of Systematic Reviews. John Wiley \& Sons, Ltd.

Conde-Agudelo, Agustin and José L. Díaz-Rossello. 2016. "Kangaroo Mother Care to Reduce Morbidity and Mortality in Low Birthweight Infants." Cochrane Database of Systematic Reviews 2016(8).

Lee, Tzu Ying, Ting Ting Lee, and Su Chen Kuo. 2009. "The Experiences of Mothers in Breastfeeding Their Very Low Birth Weight Infants." Journal of Advanced Nursing 65(12):2523-31.

Mekonnen, Alemayehu Gonie, Sisay Shewasinad Yehualashet, and Alebachew Demelash Bayleyegn. 2019. "The Effects of Kangaroo Mother Care on the Time to Breastfeeding Initiation among Preterm and LBW Infants: A Meta-Analysis of Published Studies." International Breastfeeding Journal 14:12.

Nabiwemba, Elizabeth L., Lynn Atuyambe, Bart Criel, Patrick Kolsteren, and Christopher Garimoi Orach. 2014. "Recognition and Home Care of Low Birth Weight Neonates: A Qualitative Study of Knowledge, Beliefs and Practices of Mothers in Iganga-Mayuge Health and

Demographic Surveillance Site, Uganda." BMC Public Health 14:546.

Ncube, Rosinah K., Hilary Barlow, and Pat M. Mayers. 2016. "A Life Uncertain - My Baby's Vulnerability: Mothers' Lived Experience of Connection with Their Preterm Infants in a Botswana Neonatal Intensive Care Unit." Curationis 39(1).
Neogi, Sutapa B, Monika Chauhan, Jyoti Sharma, Preeti Negandhi, and Ghanshyam Sethy. 2016. "Rolling out of Kangaroo Mother Care in Secondary Level Facilities in Bihar-Some Experiences." Indian Journal of Public Health 60(4):302.

Norén, Josefine, Kerstin Hedberg Nyqvist, Christine Rubertsson, and Ylva Thernström Blomqvist. 2018. "Becoming a Mother - Mothers' Experience of Kangaroo Mother Care." Sexual and Reproductive Healthcare 16:181-85.

Parmar, Veena Rani, Ajay Kumar, Rupinder Kaur, Siddharth Parmar, D. Kaur, Srikant Basu, Suksham Jain, and Sunny Narula. 2009. "Experience with Kangaroo Mother Care in a Neonatal Intensive Care Unit (NICU) in Chandigarh, India." The Indian Journal of Pediatrics 76(1):25-28.

Premji, Shahirose S., Gianella Pana, Genevieve Currie, Aliyah Dosani, Sandra Reilly, Marilyn Young, Marc Hall, Tyler Williamson, and Abhay K. Lodha. 2018. "Mother's Level of Confidence in Caring for Her Late Preterm Infant: A Mixed Methods Study." Journal of Clinical Nursing 27(5-6):e1120-33.

Rossman, Beverly, Michelle M. Greene, Amanda L. Kratovil, and Paula P. Meier. 2017. "Resilience in Mothers of Very-Low-BirthWeight Infants Hospitalized in the NICU." Journal of Obstetric, Gynecologic \& Neonatal Nursing 46(3):434-45.

Schenk, Laura K. and Jane H. Kelley. 2010. "Mothering an Extremely Low Birth-Weight Infant." Advances in Neonatal Care 10(2):8897.

Schuler, Christina, George Edward Ntow, and Faith Agbozo. 2019. "Mothers' Experiences with Neonatal Care for Low Birth Weight Infants at Home; A Qualitative Study in the Hohoe Municipality, Ghana." Journal of Pediatric Nursing 45:e44-52.

Scime, Natalie V., Adam G. Gavarkovs, and Katie H. Chaput. 2019. "The Effect of Skin-to-Skin Care on Postpartum Depression among Mothers of Preterm or Low Birthweight Infants: A Systematic Review and Meta-Analysis." Journal of Affective Disorders 253:376-84. 
Shonkoff, J. P., Garner, A. S.Committee on Psychosocial Aspects of Child and Family Health, Committee on Early Childhood, Adoption, and Dependent Care, \& Section on Developmental and Behavioral Pediatrics. (2012). The lifelong effects of early childhood adversity and toxic stress. Pediatrics, 129(1), e232-e246. doi.org/10.1542/peds.2011-2663.

Solehati, T., Kosasih, C.E., Rais., Y., Fitriyah, N., Darmayanti., Puspitasari., R.N., . Kangaroo Mother Care In Low Baby Weight: A Systematic Review. (2018). 234-445-1-SM.

Tricco, A. C., Lillie, E., Zarin, W., O'Brien, K., Colquhoun, H., Kastner, M., ... Straus, S. E. (2016). A scoping review on the conduct and reporting of scoping reviews. BMC Medical Research Methodology, 16(1), 1-10. https://doi.org/10.1186/s12874-016-0116-4
Véras, Renata Meira and Martha Traverso-Yépez. 2011. "The Kangaroo Program at a Brazilian Maternity Hospital: The Preterm/Low-Weight Babies' Health-Care under Examination." Nursing Inquiry 18(1):84-91.

Who. (2014). Comprehensive Implementation Plan on Maternal, Infan dan Young Child Nutrision. URL:http://etd. Respiratory.ugm.ac.id

Woodward, L. J., S. Bora, C. A. C. Clark, A. Montgomery-Hönger, V. E. Pritchard, C. Spencer, and N. C. Austin. 2014. "Very Preterm Birth: Maternal Experiences of the Neonatal Intensive Care Environment." Journal of Perinatology 34(7):555-61.

practice for maintenance of vascular access device patency. A cross-sectional survey. International Journal of Nursing Studies, 52(11), pp.1678-1685. 